University of New Haven

University of

New Haven

Digital Commons@ New Haven

2016

\title{
Overcoming the Barriers to Green Procurement in the County: Interest Groups and Administrative Professionalism
}

Christy Smith

University of New Haven, CDSmith@newhaven.edu

Jessica N. Terman

George Mason University

Follow this and additional works at: https://digitalcommons.newhaven.edu/publicadministrationfacpubs

Part of the Public Affairs, Public Policy and Public Administration Commons

\section{Publisher Citation}

Smith, C., Terman, J. N. (2016). Overcoming the Barriers to Green Procurement in the County: Interest Groups and Administrative Professionalism. Journal of Public Procurement, 16(3), 259-285. http://www.emeraldinsight.com/doi/abs/10.1108/

JOPP-16-03-2016-B001

\section{Comments}

This is the authors' accepted version of the article published in Journal of Public Procurement, 16(3), pp. 259-285. The version of record can be found at http://www.emeraldinsight.com/doi/abs/10.1108/JOPP-16-03-2016-B001 


\title{
OVERCOMING THE BARRIERS TO GREEN PROCUREMENT IN THE COUNTY: INTEREST GROUPS AND ADMINISTRATIVE PROFESSIONALISM
}

\begin{abstract}
Scholars and practitioners have come to understand the important role of local governments in the causes and effects of climate change. The literature has examined both the substantive and symbolic determinants of urban sustainability policies in addition to the implementation issues associated with those policies. At the heart of these policies is the idea that local governments have the desire and ability to engage in socially and environmentally responsible practices to mitigate climate change. While important, these studies are missing a key component in the investigation of local government involvement in sustainability policies: government purchasing power. This study examines the effect of administrative professionalism and interest group presence on the determinants of green procurement in the understudied context of counties in the United States.
\end{abstract}

\section{INTRODUCTION}

Scholars and practitioners have come to understand the important role of local governments in the causes and effects of climate change (Sharp, et al., 2010). The literature has examined both the substantive and symbolic determinants of urban sustainability policies in addition to the implementation issues associated with those policies (Hawkins, et al., 2015; Terman and Feiock, 2014). At the heart of these policies is the idea that local governments have the desire and ability to engage in socially and environmentally responsible practices to mitigate climate change. While crucially important, these studies are missing a key component in the investigation of local government involvement in sustainability policies: public procurement.

Through their purchase of public goods and services, local governments have the ability to change market practices by mandating the use of products and services that have a reduced effect on human health and the environment. However, at odds with the adoption of some of these policies are concerns from administrative professionals about the cost of "going green" (Coggburn, 2004) and the pressure brought by interest groups and manufacturers of "brown" industries that have traditionally been the providers of public goods and services (Plas and Erdmenger, 
2000). This study examines the effect of administrative professionalism and interest group presence on the determinants of green procurement in the understudied context of counties in the United States.

We find that counties with heightened administrative professionalism in both sustainability and more generally will be more likely to adopt green procurement practices. This suggests that, contrary to previous research on green procurement (NACo, 2012), some governments are beginning to perceive green products as feasible options for public purchase and consumption. Furthermore, this supports extant research underscoring the policy choices of governments with professional management structures (Bae and Feiock, 2013). While we do not find evidence that the heightened presence of green or brown industries affects green procurement adoption, we do find that the heightened presence of environmental advocacy groups has a positive influence on the adoption of green procurement practices. This is supported by the literature on local government sustainability policy, which asserts that interest group demands influence resource allocation and the prioritization of local government policy (Hawkins, et al., 2015).

In the first section, we define and provide a review of the contemporary literature on green procurement and place it within the larger context of local sustainability policy. We close the literature review with a brief discussion of the understudied context of county governments and the role that they can play in advancing green procurement practices. Theory and hypotheses linking interest group presence and administrative professionalism to green procurement are then tested and the results are discussed. We conclude with a discussion of the implications of our findings and future research in the study of green public procurement.

\section{LITERATURE REVIEW}

\section{What is Green Procurement?}

Green procurement, also referred to as environmentally preferable purchasing (EPP), is defined as "selecting products or services that have a lesser or reduced effect on human health and the environment when compared with competing products or services that serve the same purpose" (EPA, 2000). Green procurement is further understood as using environmental criteria in supplier selection and product evaluation (New et al., 2002). EPP includes mandating the procurement of products certified to meet environmental or energy efficiency standards (e.g. "ecolabeled"); specifying supply chain practices (CEC, 2003) and giving consideration to the total cost of ownership by using life-cycle assessment (OECD, 2000) and total life-cycle costing tools (Ergmenger, 2003). 
Although green alternatives have become increasingly important to consumers (Drumwright, 1994; New et al, 2002; Webb, Mohr and Harris, 2008), ${ }^{i}$ governments in both the US and Europe have been slow to institutionalize them (Michelsen and de Boer, 2009; Bouwer et al., 2006). A 2012 survey of government purchasers found that 46 of the 236 surveyed included green purchasing practices in their organization's formal, strategic procurement plan (NIGP, 2012). Barriers to green procurement include perceived cost difference, product availability and performance differences (NIGP, 2001). Underscoring these barriers is the assumption that the green product market is too underdeveloped for competition between firms to drive down prices and create superior products.

These concerns about price are compounded by the fact that green procurement does not necessarily fit into the traditional values of procurement - best quality for best price (Arrowsmith and Hartley, 2002). Generally, lowest price prevails in purchasing decisions and, when green products were first introduced into the market, their pricing was considered prohibitive and their quality was either questionable or found lacking (Case, 2004). Even as new and better quality green products become available (Plas and Ergmenger, 2000), these original perceptions of quality and price persist, as well as a widely-perceived lack of specific knowledge about EPPs (NIGP, 2012; Guenther et al., 2010; Bouwer et al., 2006). However, advocates of green procurement suggest that the purchasing power of government (i.e. purchasing consortia, collaborative product contracts) can transform the market, which will eventually result in price decreases and a competitive market (CEC, 2003; Habeck, 2003). ${ }^{\text {ii }}$

\section{Determinants of Green Procurement}

Few studies investigate the adoption of green procurement in the public sector (Coggburn, 2004). Some scholars suggest that green procurement, like other socially responsible innovations in government, are the result of entrepreneurial purchasing departments procurement agents (Smith, 2013). Others examine whether adoption is the result of internal government factors or is adopted as a result of the external pressures of diffusion (Matisoff, 2008). More generalized research suggests that countries with the highest rates of green purchasing share several characteristics: they have strong advocates and national guidelines; green procurement guidelines and information are readily accessible through websites; they have integrated measurements of life-cycle costing and green components in contracting procedures; and they have adopted their own environmental management systems (Bouwer et al., 2006). Above all, there is fairly wide consensus that larger, more affluent 
governments have higher rates of green procurement policy adoption (Michelsen and de Boer, 2009; Smith, 2013).

With the lack of studies on green procurement practices, we take inspiration for this study from the broader literature on local adoption of sustainability and environmentally friendly policies. Scholars have examined the influence that governance incentive structures (i.e. councilmanager vs. mayor-council), interest group influence and capacity have on the adoption of sustainability policies (Matisoff, 2008). Bae and Feiock (2013) show that council-manager governments are more likely to adopt sustainability practices aimed at internal government functions (rather than those in the community). The assumption is that, in an effort to curry favor with voters, elected officials (i.e. mayors) will want their sustainability policies to be more visible in the community. Although the empirical results across studies have been inconsistent (Krause et al., 2014; Hawkins, et al., 2015), citizen and interest group support for sustainability practices are often assumed to influence the development of sustainability policies. Other literature highlights the role that local government collaboration and involvement in professional climate protection networks (i.e. ICLEI membership) has on resource allocation for sustainability (Feiock, et al., 2014).

Given the existing research base on the adoption of sustainability policies, the lack of studies on the determinants of green procurement represents a noticeable gap. Green procurement policies represent a substantive commitment to institutionalize sustainability in internal government practices. Since local governments are such considerable purchasers of goods and services (the Center for a New American Dream currently estimates state and local government purchasing at over $\$ 400$ billion annually), their exercise of purchasing power may have much greater effects on overall environmental and human health than the broader, potentially more symbolic policy choices. We contribute to the literature on the local adoption of sustainability policies, in addition to the broader public procurement literature, by examining the effect of professional administration and interest group presence on green procurement policy adoption, as defined by the National Association of Counties (NACo).

\section{Green Procurement in County Governments}

Unlike state governments and municipalities, counties are often overlooked as a unit of analysis (Benton, 2002). They are often perceived as constrained by the state, tasked with facilitating elections, tax collection, and law enforcement (Benton and Rigos, 1985; Deslatte, 2015) and lacking the autonomy that cities often enjoy (Feiock et al., 2008). 
Despite the perceived limitations of counties, they have considerable authority in land use and development determinations (Deslatte, 2015; Feiock et al., 2008), making it important to understand how counties are organized, how they operate administratively and are influenced by interest group pressure.

Within the context of procurement, research suggests that counties are better able to introduce green procurement because they are more likely to engage in exploratory, or innovative behavior, and that the movement toward green procurement can be largely traced to environmental advocates and other interest groups (Clement et al. 2003). Furthermore, counties have the ability to serve as organizing entities or network leaders for the local governments that they contain. Thus, green procurement practices may have the ability to diffuse downward or county governments may provide cooperative purchasing vehicles that make green procurement more feasible for municipalities. All of this is to say that counties remain an important unit of analysis for examining the adoption of green procurement policy.

\section{THEORETICAL FRAMEWORK}

\section{Interest Group Presence: Advocates and Suppliers}

Local governments, such as counties, are particularly susceptible to the preferences of local interest groups because they are expected to respond to local pressures and conditions more readily than national or state governments. They often also have smaller political markets, which make political and administrative decision-makers particularly vulnerable to interest group opposition. Furthermore, unlike municipalities, counties are often unincorporated with diffuse interests and, therefore, they may be more likely to be influenced by interest groups (Deslatte, 2015). In the context of EPP, two such interests include advocates for greener public policies and potential providers and potential suppliers for public goods and services.

\section{Advocates: Environment Interest Groups}

Environmental interests will put pressure on county governments to adopt EPP policies. Their challenge will be to overcome the perceived costs of green procurement. For example, $41 \%$ of county respondents to a survey conducted by the National Association of Counties (NACO) said that their county does not purchase green products because they "cost more than traditional products" (NACO, 2012, 4; also see Michelsen and de Boer, 2009). We suspect that the significant presence of environmental interests in a given county will be able to overcome the political risk associated with adopting EPP policies by making it more politically risky 
to not adopt policies. Furthermore, environmental groups will also be able to communicate the benefits of adopting EPP policies, thereby convincing county voters that these policies will indeed be in the long-term interest of the county and/or are not as costly as perceived. Thus, environmental interests are expected to exert direct pressure on county government officials in addition to reducing political resistance in the electorate to the adoption of EPP policies. As a result, we suspect that counties with a greater number of environmental groups will be more likely to engage in green procurement practices $\left(H_{l}\right)$.

\section{Suppliers: Green and Brown Industries}

Potential providers and suppliers of public goods and services could be perceived as falling into two general categories: (1) green industries focused on sustainability and renewable technologies that EPP policies would potentially benefit and (2) brown (fossil fuel-oriented or chemical production) industries that EPP policies would adversely affect. The former would support EPP adoption and might, therefore, reduce wider county opposition. Additionally, the heightened presence of green industries might make counties more likely to adopt EPP because there would be more providers in the marketplace. Additional providers would be likely create a more competitive market environment, therefore making EPP policies less expensive (CEC, 2003; Habeck, 2003).

For example, many counties have seen an increase in training programs in green technologies and infrastructure. This is largely due to organizations such as the Interstate Renewable Energy Council (IREC), which has been heavily involved in credentialing programs in energy efficiency techniques and permitting and siting issues as they relate to clean energy infrastructure. This credentialing has created more certainty and standardization in the market for both educational institutions and individuals looking to be trained in the latest clean energy technologies. We expect that these facilities not only provide the possibility for more green industry and competition, but that they also change the industrial makeup of a county such that there may also be a push for additional companies involved in green products and technologies to enter the market. As a result, we suspect that counties with a greater number of green industries will be more likely to engage in green procurement practices $\left(\mathrm{H}_{2}\right)$.

Alternatively, brown industries can create a barrier to EPP adoption (Matisoff, 2008). Brown, or environmentally inferior, industries (Marron, 1997), refer to firms whose products and materials have traditionally been purchased by governments and generally do not contemplate potential negative environmental impacts. Because 
procurement has been identified as an important tool in the development of local companies (Preuss, 2007), it is expected that county procurement activities would normally seek to facilitate the development of their local economies (Matisoff, 2008) regardless of whether they represent green or brown technologies. EPP policies represent a reduction in demand for their local products. Furthermore, the heightened presence of these industries suggests that there is less of a market for EPP products, which make these policies more expensive. As a result, we suspect that counties with a greater number of brown industries will be less likely to engage in green procurement practices $\left(H_{3}\right)$.

\section{Professional Administration: Professional Networks and Bureaucratic Structure}

Professional administration is believed to influence the adoption of innovative and socially responsible procurement practices, such as vendor diversity and e-procurement (Arrowsmith, 2010; McCrudden, 2004). While this has not always been the case with green procurement (Coggburn, 2004), we suggest that the definition of responsible procurement may be expanding to include environmental concerns. Additionally, the literature on the effects of professional management indicates that when governments are run by individuals with heightened administrative expertise and stewardship, decision-makers will be insulated from the preferences of the electorate (Deslatte, 2015; Carr 2015), which may be less environmentally or socially responsible.

We frame professional administration in two ways: (1) the professionalism and capacity of individuals working in county agencies and (2) the bureaucratic structure of county government. The causal mechanism for the former is administrator response to the socialization, professionalization and information diffusion that occurs across individuals in counties through professional organizations and trade associations. The causal mechanism for the latter is the incentive structure for the county chief administrator (elected or appointed) and prioritization of environmental and sustainability responsibilities, through agency assignment, which prioritizes some government functions over others.

\section{Professional Networks}

Green procurement adoption is expected to spread through professional organizations through the use of communication networks that encourage innovation adoption and promote professional capacity (Perkins and Neumayer, 2008; Busch and Jörgens, 2005; Studlar, 1999; Savage, 1985). There is considerable evidence to suggest that administrators rely on professional norms in their decision-making 
(Keiser, 2010) and that these norms are informed and facilitated by professional networks. Furthermore, these innovations create professional accountability between administrators that are often independent of the goals and preferences of the governments for which these administrators work.

We understand the effect that individual professionalization has on adoption of EPPs in terms of (1) government administration more generally and (2) procurement more specifically. With regard to professionalism more broadly, we suggest that involvement in professional networks aimed at the management of financial resources and governmental solvency will facilitate the adoption of green procurement. The Government Finance Officers Association (GFOA) is one such organization. GFOA seeks to enhance and promote the professional management of governmental financial resources through sharing best practices, providing educational and training opportunities, and by facilitating networking among its members. This association annually recognizes top performing public organizations in the areas of budgeting, financial reporting, and innovation. The GFOA Award for Excellence focuses on innovations in financial management, including areas such as accounting, technology, investment management, and debt administration (gfoa.org). Recipients of this award not only have the benefit of organizational membership but they also have recognition for innovativeness in the field. Individuals working for counties that are GFOA Award recipients will be more likely to be part of influential networks and will have exposure to the most innovative practices. We expect that they will also influence their governments to be leaders in green procurement. As a result, we suspect that counties that have been recipients of the GFOA Award for Excellence will be more likely to engage in green procurement practices $\left(H_{4}\right)$.

With regard to procurement professionalization more specifically, we suggest that involvement in organizations such as the National Institute of Governmental Purchasing (NIGP) will advance best practices in green procurement. NIGP hosts expos and forums for public procurement practitioners so that the most current information can be shared across all levels of government and national borders. They co-sponsor the biennial International Public Procurement Conference, where procurement professionals from all over the world gather to share practitioner- and research-based innovations. For all of these reasons, membership in NIGP is regarded in this study as engaging in professional development/enhancing professionalization within an organization, which, we suspect, will make counties more likely to engage in green procurement practices $\left(\mathrm{H}_{5}\right)$. 


\section{Bureaucratic Structure}

Bureaucratic structure is defined in two different ways: county governance structure and sustainability agency assignment. While counties generally serve as an intermediary between the state and its citizens, they have undergone reforms in terms of governance structure in order to better carry out their responsibilities (Benton and Rigos, 1985). Many counties have now adopted a commission-administrator structure that provides for professional (as opposed to elected) executive leadership in conjunction with a multi-member commission (Feiock et al., 2008). This professional leadership frees counties to engage in more socially responsible policy choices such as green procurement. Additionally, professional managers will be less likely to curry favor with political interests in order to stay in power (Bae and Feiock, 2013) and more likely to have an interest in wider government operations and community benefits (Zhang and Feiock, 2010). Thus, we suspect that counties with commission-administrator structures will be more likely to engage in green procurement practices $\left(H_{6}\right)$.

While local governments have become increasingly involved in sustainability policy, there are considerable differences across counties in terms of the location and assignment of actual sustainability offices. "The position of a program within the bureaucratic structure of government whether as an independent unit or a subpart of another...can meaningfully affect its priorities" (Krause, et al., 2014). Having a stand-alone sustainability office suggests not only that a government takes sustainability and environmentalism seriously but that it also has the implementation infrastructure to support these policies. Furthermore, a county that invests in a stand-alone sustainability office can be perceived as making a real, tangible investment in creating or maintaining sustainability in their community. Counties with a sustainability office, at least on the surface, would indicate that the organization has institutionalized ideological change demanded by their constituents, such as a green procurement policy. This may or may not reflect fiduciary efficiencies within the organization, but rather extends to include more farreaching environmental and/or sustainability objectives and indicates heightened professionalization. Thus, we suspect that counties with standalone sustainability offices will be more likely to engage in green procurement practices $\left(H_{7}\right)$.

\section{Sample}

\section{RESEARCH DESIGN}


As noted above, the unit of analysis in this study is counties. To estimate this analysis, a stratified random sample - based on population size - was taken. An initial sample of 300 counties was taken: 100 counties under a population under 50,000, 100 counties with populations between 50,000 and 500,000, and 100 counties with populations greater than 500,000. After additional research and background interviews with county officials, the decision was made to drop counties with populations less than 50,000 because the majority of these counties do not have purchasing departments. Of the 200 counties remaining in the study, data were collected for 174 because of the availability of relevant data. iii

\section{Data and Measurement \\ Green Procurement Practices}

The measurement of the dependent variable, green procurement practices, was inspired by the National Association of Counties' (NACo) Green Purchasing Toolkit, which has identified purchasing practices indicative of innovative green procurement. These practices include (1) whether counties have a formal environment purchasing policy (EPPs) in place, (2) whether their request for proposals (RFPs) include eco-label language (i.e. Energy Star requirements), (3) whether their RFPs include green criteria specifications (i.e. "energy efficient," "low toxicity," "compostable,") and (4) whether they communicate green purchasing goals and/or requirements to vendors. The use of the NACo Green Purchasing Toolkit is useful as a benchmark for green purchasing because this is one of the few organizations that has developed best practices and guidance specifically aimed at county purchasing departments. Furthermore, NACo's guidance is accessible to non-members; therefore, it is expected that counties seeking legitimacy in relation to their green procurement practices will follow their guidance. The dependent variable, overall, was measured as an additive index of the four aforementioned NACo practices (formal EPP policy, eco-label language included in RFPs, green criteria specifications in RFPs, and whether or not green goals/requirements are communicated to vendors) $(\square=0.687)$. These measures are memorialized in Table 1.

Table 1: Codebook and Measurement 


\begin{tabular}{|c|c|c|}
\hline EPP Practices & $\begin{array}{l}\text { Additive index of EPP } \\
\text { practices }\end{array}$ & $\begin{array}{l}\text { County purchasing } \\
\text { departments }\end{array}$ \\
\hline \multicolumn{3}{|l|}{ Interest Group } \\
\hline \multicolumn{3}{|l|}{ Presence } \\
\hline $\begin{array}{l}\text { Environmentalist } \\
\text { concerns }\end{array}$ & $\begin{array}{l}\text { Environmental nonprofits with } \\
\text { receipts } \geq \$ 50,000\end{array}$ & $\begin{array}{l}\text { NCCS matched with } \\
\text { NTEE database (990 } \\
\text { forms) }\end{array}$ \\
\hline $\begin{array}{l}\text { Renewable } \\
\text { technologies }\end{array}$ & $\begin{array}{l}\text { IREC-credentialed providers } \\
\text { w/onsite training in the county }\end{array}$ & $\begin{array}{l}\text { IREC Clean Energy } \\
\text { Directory }\end{array}$ \\
\hline Chemical industry & $\begin{array}{l}\text { Number of chemical } \\
\text { production employees in the } \\
\text { state }\end{array}$ & $\begin{array}{l}2012 \text { Economic } \\
\text { Census }\end{array}$ \\
\hline $\begin{array}{l}\text { Oil and gas } \\
\text { industry }\end{array}$ & $\begin{array}{l}\text { Number of petroleum } \\
\text { production employees in the } \\
\text { state }\end{array}$ & $\begin{array}{l}2012 \text { Economic } \\
\text { Census }\end{array}$ \\
\hline \multicolumn{3}{|l|}{ Professionalism } \\
\hline NIGP membership & County NIGP membership & $\begin{array}{l}\text { NIGP membership } \\
\text { records }\end{array}$ \\
\hline GFOA excellence & $\begin{array}{l}\text { Recipient of GFOA Award of } \\
\text { Excellence }\end{array}$ & $\begin{array}{l}\text { GFOA membership } \\
\text { records }\end{array}$ \\
\hline $\begin{array}{l}\text { Sustainability } \\
\text { office } \\
\text { Appointed } \\
\text { executive }\end{array}$ & $\begin{array}{l}\text { Presence of county } \\
\text { sustainability office }\end{array}$ & $\begin{array}{l}\text { County department } \\
\text { directories }\end{array}$ \\
\hline \multicolumn{3}{|c|}{ County Affluence and Economies of Scale } \\
\hline Population density & $\begin{array}{l}\text { County population per square } \\
\text { mile }\end{array}$ & 2010 Census Bureau \\
\hline Median income & Median income & 2010 Census Bureau \\
\hline
\end{tabular}

Data on green procurement practices index was based on a thorough search of county websites, which was conducted from February to April 2013. Each website was examined for evidence of engaging in environmentally preferable purchasing. In order to ensure reliability and prevent data collection, two additional reviewers were engaged to evaluate the county websites. There were no material differences in the findings across the three data collection reviewers. ${ }^{\text {iv }}$

Evaluating online source material is suitable because the sharing of county purchasing manuals online has become a common practice. Additionally, because consumer pressure has been found to be a driver for an increase in the use of environmental criteria in supplier selection (New et al., 2002), many counties are eager to demonstrate to their communities, and potential state and federal grantors, that they are developing green purchasing practices. $^{\mathrm{v}}$ One way to do this is to make that information available through their websites. 
Each item in the green procurement index was operationalized in the following manner. Environmentally Preferable Purchasing Policy (EPP) was determined by whether counties had mandated use of EPP products in at least one of its purchasing areas. ${ }^{\mathrm{vi}}$ This is determined by examining the standard operating procedures (SOPs) set forth by each county purchasing department. These SOPs provide guidance for all County entities engaged in purchasing. To determine whether or not a county had RFPs that included eco-labels, RFP solicitations and bidding documents were examined. In most cases, these documents are required to be public and are either posted online or available for review by contacting the county purchasing office. Of observed RFPs, labels such as LED, EnergyStar, LEED Silver Standard, Green Seal standards, and Envirochemical Synergy requirements were observed. If any of these EcoLabel RFPs were observed, the scorecard was marked yes. To determine whether counties had RFPs with green specifications, all open RFPs were analyzed to determine whether any of the specifications were green based on the NACo Toolkit referenced above. Green specifications such as zero VOC paint, recycled content, hybrid and electric automobiles, and biodegradable, among others, were all observed in county RFPs.

Lastly, for the variable of whether green goals were communicated to vendors, websites were reviewed for any notice that was provided to vendors regarding a preference for green products and/or services. Most county purchasing websites have a "Doing Business" section, which includes information for vendors about how to access RFPs and what kind of products and/or services the county procures. Other counties prepare vendor packets and brochures that included their green purchasing policy and/or recycled materials preference while others include detailed standard terms and conditions for doing business with the county, within which green goals are embedded. If a county made clear their preference for green products, either through their purchasing homepage, in their standard terms and conditions, in information prepared specifically for vendors or individuals seeking to contract with the county, or some other way not noted above, the scorecard was marked yes. Table 2 shows the breakdown of green procurement practices based on population groupings.

Table 2: EPP Practices and Population Groupings

$50,000-500,000+$
Total

499,999 $(\mathrm{n}=95)$ 
$(\mathrm{n}=79)$

\begin{tabular}{|c|c|c|c|c|c|c|}
\hline & $\mathrm{N}$ & $\mathrm{Y}$ & $\mathrm{N}$ & Y & $\mathrm{N}$ & $\mathrm{Y}$ \\
\hline Green Purchasing Plan & 61 & 18 & 54 & 41 & 115 & 59 \\
\hline Eco-Labels in RFPs & 78 & 1 & 81 & 14 & 159 & 15 \\
\hline Green Specifications in RFPs & 76 & 3 & 75 & 20 & 151 & 23 \\
\hline $\begin{array}{l}\text { Green Product Preference } \\
\text { Communicated to Vendors }\end{array}$ & 75 & 4 & 77 & 18 & 152 & 22 \\
\hline & \multicolumn{2}{|c|}{ Total } & \multicolumn{2}{|c|}{ Total } & \multicolumn{2}{|c|}{ Total } \\
\hline 0 Practices & \multicolumn{2}{|c|}{60} & \multicolumn{2}{|c|}{48} & \multicolumn{2}{|c|}{108} \\
\hline 1 Practices & \multicolumn{2}{|c|}{13} & \multicolumn{2}{|c|}{20} & \multicolumn{2}{|c|}{33} \\
\hline 2 Practices & \multicolumn{2}{|c|}{5} & \multicolumn{2}{|c|}{17} & \multicolumn{2}{|c|}{22} \\
\hline 3 Practices & \multicolumn{2}{|c|}{1} & \multicolumn{2}{|c|}{5} & \multicolumn{2}{|c|}{6} \\
\hline 4 Practices & \multicolumn{2}{|c|}{0} & \multicolumn{2}{|c|}{5} & \multicolumn{2}{|c|}{5} \\
\hline Total & \multicolumn{2}{|c|}{$\begin{array}{c}79 \\
(45 \%)\end{array}$} & \multicolumn{2}{|c|}{$\begin{array}{c}95 \\
(55 \%)\end{array}$} & \multicolumn{2}{|c|}{$\begin{array}{c}174 \\
(100 \%)\end{array}$} \\
\hline
\end{tabular}

\section{Interest Group Presence}

Environmental interest group presence was measured by examining the number of nonprofit organizations filing IRS Form 990 at the county level. This data was collected from the National Center for Charitable Statistics (NCCS). The NCCS counted 16,789 registered Environmental public charities filing Form 990, required for tax exempt organizations with gross receipts greater than or equal to $\$ 50,000$ (www.irs.gov/), in the spring of 2013; the sample of counties was compared to the organizations falling within NTEE (National Taxonomy of Exempt Entities) category EN (Environment and Animals) to determine how many of them fell within the selected counties.

Renewable technologies industry and good availability was measured by using the clean energy training directory developed by the Interstate for Renewable Energy Council (IREC). The Clean Energy Directory consists of IREC-credentialed providers that offer certificates and training in renewable energy and energy efficiency. The specific operationalization that we used was the number of IREC-credentialed providers in a given county with onsite training. These credentialed providers influence the market supply for building and green products in a given region. This data was collected during April 2013.

The presence of oil and gas production and chemical manufacturing industry groups was measured by using the 2012 economic census data of state manufacturing sectors. The oil and gas industry was operationalized using the number of petroleum production employees. 
${ }^{\text {vii }}$ Chemical manufacturing industry presence was operationalized using the number of chemical production employees.

\section{Administrative Professionalism}

County professionalism was operationalized in four different ways: whether or not the county has been a recipient of a Government Finance Officers Association (GFOA) Award of Excellence, whether a county was a member of the National Institute of Governmental Purchasing (NIGP), county form of government (appointed not elected executive) and whether the county has a stand-alone sustainability office. The data for GFOA Award Excellence and NIGP membership was collected using membership and organization documents, which were, in some cases, followed-up by phone calls to counties and the professional organizations for verification. Data on county form of government was collected by examining the county charters in the sample. And, lastly data on whether or not the county has a stand-alone sustainability office as opposed to a single program embedded in a larger office or program was collected through county organizational charts and followed-up by phone calls for clarification.

\section{Control Variables}

We control for county affluence and economies of scale, which we expect will be positively associated with green purchasing practices because of the perceived expense of environmentally friendly practices. Furthermore, empirical evidence suggests that that states with slack resources are more likely to adopt government innovations (Walker, 1969). We believe that this applies to green purchasing practices. These control variables were operationalized as population per square mile and median income.

\section{Analytic Technique and Model}

The dependent variable is a count with substantive values ranging from zero to four. We do not treat this dependent variable as ordinal because zero has a true meaning, as do each of the other values of the dependent variable. As Table 1 suggests, there is overdispersion in the count dependent variable. Thus, negative binomial regression was used to examine the influence of our variables of interest on the count of green procurement practices. However, as the descriptive statistics of the dependent variable suggest, more than half of the sample adopted zero green procurement practices at the time of data collection. Therefore, we decided to also conduct logistic regression for whether or not counties had adopted at least one of the NACo specified procurement practices. This 
enabled us to determine if there were particular county characteristics that influenced the adoption of at least one EPP practice but did not affect whether they adopted more than one.

\section{RESULTS}

Table 2 indicates the breakdown of the dependent variable. Of the 174 counties examined, a third had some kind of written policy for purchasing environmentally preferable products, fewer than $10 \%$ used eco-labels in their RFPs, $13 \%$ used green specifications in their RFPs, and almost $13 \%$ communicated to vendors a preference for environmentally preferable products. The majority of counties (104 out of 174) actually adopted no green practices. However, $19 \%$ had one item, almost $13 \%$ had two items, and 3\% had three items and four items, respectively. Clearly, many counties have still not implemented environmentally preferable purchasing practices. However, some counties have excelled at it: at least one county in the study banned all Styrofoam purchases while another banned the use of all virgin wood.

As the descriptive statistics in Table 3 indicate, counties had an average of 58 environmental nonprofits. Of our sample, $60 \%$ of counties had NIGP membership; $11 \%$ had received the GFOA Award of Excellence and only $8 \%$ had stand-alone sustainability offices. Commissionadministrator county governments made up $54 \%$ of our sample.

\begin{tabular}{|c|c|c|c|c|}
\hline \multicolumn{5}{|c|}{ Table 3: Descriptive Statistics } \\
\hline & Mean & SD & Min & Max \\
\hline EPP Practices & 0.661 & 1.02 & 0 & 4 \\
\hline \multicolumn{5}{|l|}{ Interest Group Presence } \\
\hline $\begin{array}{l}\text { Environmental } \\
\text { nonprofits }\end{array}$ & 57.799 & 63.411 & 1 & 400 \\
\hline Renewable technologies & 0.322 & 0.974 & 0 & 10 \\
\hline Chemical establishments & 25.489 & 36.891 & 0 & 305 \\
\hline Oil/gas establishments & 31.851 & 103.808 & 0 & 1060 \\
\hline \multicolumn{5}{|l|}{ Professionalism } \\
\hline NIGP membership & 0.603 & 0.491 & 0 & 1 \\
\hline GFOA excellence & 0.109 & 0.313 & 0 & 1 \\
\hline Sustainability office & 0.08 & 0.273 & 0 & 1 \\
\hline Council-manager & 0.54 & 0.499 & 0 & 1 \\
\hline \multicolumn{5}{|c|}{ County Affluence and Economies of Scale } \\
\hline Population density & 3654 & 17158 & 47 & 155779 \\
\hline Median income & $\begin{array}{l}57316.6 \\
7\end{array}$ & $\begin{array}{l}14340.0 \\
1\end{array}$ & 32479 & 120096 \\
\hline
\end{tabular}


Table 4 contains the results for both estimations. Both models yielded a statistically significant result for the likelihood ratio test of the overall models. Furthermore, the likelihood-ratio test for alpha in the negative binomial estimation was statistically significant $(\mathrm{p} \leq 0.014)$, indicating that there is evidence of overdispersion (and that negative binomial regression is the correct technique over poisson). The logit model accurately correctly classified the dependent variable at $77.7 \%$. The results in Table 4 are listed in log odds. To facilitate coefficient interpretation, our discussion here is in terms of odds ratios.

\begin{tabular}{|l|c|c|}
\hline \multicolumn{3}{|c|}{ Table 4: Green Procurement Practices } \\
\hline & $\begin{array}{c}\text { Negative Binomial } \\
\text { Estimation }\end{array}$ & Logit Estimation \\
\hline & $\square$ (Std. Error) & $\square$ (Std. Error) \\
\hline $\begin{array}{l}\text { Interest Group } \\
\text { Presence }\end{array}$ & & \\
\hline $\begin{array}{l}\text { Environmentalist } \\
\text { concerns }\end{array}$ & 0.006 & 0.010 \\
\hline Renewable & $(0.002)^{* * *}$ & $(0.004)^{* *}$ \\
technologies & 0.091 & -0.0204 \\
\hline Chemical industry & $(0.085)$ & $(0.201)$ \\
\hline Oil and gas industry & -0.003 & -0.005 \\
& $(0.004)$ & $(0.007)$ \\
\hline Professionalism & 0.001 & 0.002 \\
\hline NIGP membership & $(0.001)$ & $(0.002)$ \\
\hline GFOA excellence & 0.352 & 0.551 \\
& $(0.267)$ & $(0.412)$ \\
\hline Sustainability office & 0.170 & 0.984 \\
& $(0.331)$ & $(0.594)^{*}$ \\
\hline Appointed executive & 0.690 & 1.65 \\
& $(0.357)^{*}$ & $(0.712)^{* *}$ \\
\hline County Affluence and Economies of Scale & 0.697 \\
\hline Population density & 0.125 & $(0.386)^{*}$ \\
\hline Median income & $(0.065)^{*}$ & 0.095 \\
& 0.00 & $(0.112)$ \\
\hline Constant & $(0.00)^{* * *}$ & 0.00 \\
& -3.161 & $(0.00)^{* * *}$ \\
\hline * p $\leq 0.1$ & $(0.607)^{* * *}$ & -4.737 \\
$* *$ p $\leq 0.05$ & $L R \chi^{2}=40.3 * * *$ & $(1.041)^{* * *}$ \\
$* * * p \leq 0.01$ & & $L R \chi^{2}=48.24^{* * *}$ \\
\hline
\end{tabular}


Of the variables representing interest group presence, the number of environmental nonprofits was statistically significant in both models, with a stronger effect for the logit estimation. As the results for the negative binomial model show, for every additional environmental nonprofit in the county, the expected number of green procurement practices increases by $0.5 \%$. The results in the logit model are only slightly higher: for every additional environment nonprofit in the county, the expected number of green procurement practices increase by $0.9 \%$.

The results of the administrative professionalism variables showed a stronger effect in the models. Receiving the GFOA Award of Excellence was not statistically associated with the count of green procurement practices. However, receiving the GFOA Award of Excellence increased the likelihood that counties would adopt at least one green procurement practice by a factor of 2.68. As the results for the negative binomial model show, having a stand-alone sustainability office increases the expected number of green procurement practices roughly $99 \%$. Similarly, having a stand-alone sustainability office increases the probability that a county adopts at least one green procurement practice by a factor of five.

The effect of median income was positively associated and statistically significant in both models; but this effect was extremely small to the point of being negligible. Population density had a statistically significant effect on the count of green practices but not whether or not counties adopted at least one green procurement practice.

\section{DISCUSSION AND CONCLUSION}

Much like the results in the broader sustainability literature, interest group presence is somewhat mixed. While environmental advocacy groups have a positive impact on the adoption of green procurement, the increased presence of green and brown industries has no statistically significant effect. This may be explained by the differences between advocacy groups and potential public goods and services providers (i.e. brown and green industries). Environmental advocacy groups often concentrate their efforts on particular governmental or industry practices. Thus, their energies are more concentrated than those of green and brown industries because the core function of the latter two is to produce goods and services (not necessarily lobby for changes to public policy).

The results of the measures of professionalism are particularly interesting. Previous survey research (NIGP, 2001) and academic studies (Michelsen and de Boer, 2009) have suggested that heightened 
professionalization, in general, may make governments less likely to adopt green procurement policies. We hypothesized the opposite and found that governments that have won the GFOA award of excellence and have commission-administrator systems are more likely to adopt green procurement practices. This may suggest that, in relation to traditional products and services, the perceived (or actual) marginal costs of green products and services are decreasing. Alternatively, county professionals may put a different value on the purchase of green products. Perhaps the traditional procurement mantra of best quality for best price (Arrowsmith and Hartley, 2002) is beginning to expand to something that includes environmental and product lifecycle concerns as noneconomic buying criteria (Drumwright, 1994).

The effect of having a stand-alone sustainability office is less surprising. The literature on the organization of attention (May, Workman and Jones, 2008; Terman, 2014) and administrative organization (Krause, et al, 2014) underscores the importance of bureaucratic structure. Not unlike individual decision-makers, governments have limited decisionmaking ability and, therefore, must prioritize particular functions over others. By having a stand-alone sustainability office, governments have already prioritized environmental concerns in addition to developing an implementation infrastructure to facilitate green procurement.

Economies of scale and affluence are also supported by the extant literature. Finding that larger and more established organizations were more likely to engage in green procurement, Michelsen and de Boer (2009) suggest that larger organizations have a greater capacity to build the knowledge required for engaging in green procurement and may be more likely to have a strategic approach to purchasing (also see Chia and Al-Hawamdeh, $2002 \&$ Brown, 2004). Alternatively, dense counties with more affluent populations may be better able to afford green procurement policies because of their economies of scale and economic resources.

There are a number of theoretical and empirical limitations in this study that can be addressed through future research. The analysis is crosssectional for all practical purposes. Thus, we cannot assert strict causation between environmental advocacy firms and county professionalism and green procurement. A study such as this requires panel data over time to assert causation. Our measures also require some refinement. The categories of green and brown industries could be better focused on specific green product areas rather than more broadly.

Additionally, we do not know why and/or how green procurement was first adopted in these counties. For example, does green procurement diffuse across regions or neighboring counties? Or, are these practices stimulated by collaborative arrangements that enable governments to 
purchase together in economies of scale? Without knowing more about why these procurement practices have been adopted, it is difficult to identify how a county can begin to institutionalize green purchasing. 


\section{REFERENCES}

Arrowsmith, S., \& Hartley, K. (2002). Introduction. In S. Arrowsmith, \& K. Hartley (Eds.), Public Procurement, Vol. 1: ix-xxvii. Cheltenham, UK: Elgar Reference Collection.

Arrowsmith, S. (2010). Horizontal Policies in Public Procurement: A Taxonomy. Journal of Public Procurement, 10(2), 149-186.

Bae, J., \& Feiock, R. (2013). Forms of government and climate change policies in US cities. Urban studies, 50(4), 776-788.

Benton, E.J. (2002). County Service Delivery: Does Government Structure Matter? Public Administration Review, 62(4), 471-479.

Benton, E.J. and Rigos, P. (1985). Patterns of Metropolitan Service Dominance: Central City and Central County Services Roles Compared. Urban Affairs Review, 20(3), 285-302.

Bouwer, M., Jonk, M., Berman, T., Bersni, R., Lusser, H., Nappa, V., Nissinen, A., Parikka,K., Szuppinger, P., and Vigano' C. (2006). “Green Public Procurement in Europe 2006 Conclusions and Recommendations." Virage Milieu \& Management by, Korte Spaarne 31, 2011 AJ Haarlem, the Netherlands.

Brown, P.D. (2004). Organizational Assimilation of Electronic Procurement Innovations. (Doctoral Dissertation). Retrieved from ProQuest Dissertations and Theses.

Busch, P. and Jörgens, H. (2005). The International Sources of Policy Convergence: Explaining the Spread of Environmental Policy Innovations. Journal of European Public Policy. 12(5), 860-884.

Case, S. (2004). "Environmental Purchasing Policies 101: An Overview of Current Environmentally Preferable Purchasing Policies." Commission for Environmental Cooperation and the North American Green Purchasing Initiative. [Online]. Available at www.cec.org. [Retrieved October 15, 2008]

Center for a New American Dream. (2015). Engaging Local Government: Harness Purchasing Power. [Online]. Available at www.newdream.org. [Retrieved August 25, 2015].

Carr, J. B. (2015). What Have We Learned about the Performance of Council-Manager Government? A Review and Synthesis of the Research. Public Administration Review. Advance Online Publication. doi: 10.1111/puar.12415

Chia, B.K. and Al-Hawamdeh, S. (2002). The Adoption of Electronic Procurement in Singapore. Electronic Commerce Research. 2(1-2), 61-73. 
Clement, S., Plas, G., Erdmenger, C. (2003). "Local experiences: green purchasing practices in six European cities.: In C. Erdmenger (Ed.), Buying into the Environment: Experiences, Opportunities and Potential for Eco-procurement (pp. 69-93). Sheffield, UK: Greenleaf.

Coggburn, J.D. (2004). Achieving Managerial Values Through Green Procurement? Public Performance \& Management Review. 28(2), 236-258.

Commission for Environmental Cooperation of North America. (2003). Green Procurement: Good Environmental Stories for North Americans [Online\}. Available at www.cec.org. [Retrieved August 25, 2015].

Deslatte, A. (2015). City-County Managers, Representation and the Dynamics of Political Markets for Growth Management (Unpublished doctoral dissertation). Florida State University, Tallahassee, FL.

Drumwright, M. (1994). Socially Responsible Organizational Buying: Environmental Concern as a Noneconomic Buying Criterion. Journal of Marketing, 58(3), 1-19.

Ergmenger, C. (2003). European Case Studies. In Republic of Austria (Ed.), Green Purcahsing Criteria: Elements from the Austria Criteria Catalgue "Check it!" (English version, pp. 14-43). Freiburg, Germany: International Council for Local Environmental Initiatives.

Feiock, R. C., Krause, R. M., Hawkins, C. V., \& Curley, C. (2014). The integrated city sustainability database. Urban Affairs Review, 50(4), 577-589.

Feiock, R., Tavares, A., and Lubell, M. (2008). Policy Instrument Choices for Growth Management and Land Use Regulation. Policy Studies Journal, 36(3), 461-480.

Guenther, E., Scheibe, L. and Farkavcov'a, V.G. (2010). “The Hurdles Analysis” As An Instrument for Improving Sustainable Stewardship. Management Research Review. 33(4), 340-356.

Habeck, M. (2003). The Power of Buying Green. Frontiers in Ecology and the Environment. $1(4), 174$.

Hawkins, C. V., Krause, R. M., Feiock, R. C., \& Curley, C. (2015). Making meaningful commitments: Accounting for variation in cities' investments of staff and fiscal resources to sustainability. Urban Studies, Advanced online publication. doi: $10.1177 / 0042098015580898$

Keiser, L. R. (2010). Understanding Street-Level Bureaucrats' Decision Making: Determining Eligibility in the Social Security Disability Program. Public Administration Review, 70(2), 247-257. 
Krause, R. M., Feiock, R. C., \& Hawkins, C. V. (2014). The administrative organization of sustainability within local government. Journal of Public Administration Research and Theory, Advanced Online Publication doi: 10.1093/jopart/muu032

Maignan, I. and Ralston, D. (2002). Corporal Social Responsibility in Europe and the US: Insights from Businesses' Self Presentations. Journal of International Business Studies, $33(3), 497-514$.

Marron, D. (1997). Buying Green: Government Procurement as an Instrument of Environmental Policy. Public Finance Review, 25(3), 85-305.

Matisoff, D.C. (2008). The Adoption of State Climate Change Policies and Renewable Portfolio Standards: Regional Diffusion or Internal Determinants? Review of Policy Research, 25(6), 527-546.

May, P. J., Workman, S., \& Jones, B. D. (2008). Organizing attention: Responses of the bureaucracy to agenda disruption. Journal of Public Administration Research and Theory, 18(4), 517-541.

McCrudden, C. (2004). Using Pubic Procurement to Achieve Social Outcomes. Natural Resources Forum, 28(4), 257-267.

Michelsen, O. and de Boer, L. (2009). Green procurement in Norway: a survey of practices at the municipal and county level. Journal of Environmental Management. 91(1), 160-167

National Association of Counties. (2012). Green Purchasing Survey: Green Purchasing in America's Counties 2011-2012. [Online]. Available at www.naco.org. [Retrieved January 14, 2013].

National Institute of Government Procurement. (2012). Sustainable Public Procurement: 2012 Survey Report. [Online]. Available at www.nigp.org. [Retrieved March 13, 2014].

National Institute of Government Procurement. (2001). Lack of Awareness of Green Procurement Initiatives Hampers Program, NIGP Survey of Green Procurement Initiatives. [Online]. Available at www.nigp.org. [Retrieved March 13, 2014].

New, S., Green, K., and Morton, B. (2002). "An Analysis of Private Versus Public Sector Responses to the Environmental Challenges of the Supply Chain." Journal of Public Procurement. 2 (1), 93-105.

Organizational for Economic Cooperation and Development. (2000) Greener Public Purchasing: Issues and Practical Solutions: Paris: OECD.

Perkins, R. and Neumayer, E. (2008). Fostering Environment Efficiency Through Transnational Linkages? Trajectories of $\mathrm{CO}_{2}$ and $\mathrm{SO}_{2}, 1980-2000$. Environment and Planning $A$. 40(12), 2970-2989. 
Plas, G. and Ermenger, C. (2000). Green Purchasing Good Practice Guide: How Local Authorities Spend their Budgets Responsibly. Freiburg, Germany: International Council for Local Environmental Initiatives.

Preuss, L., (2007). Buying into our future: sustainable initiatives in local government procurement. Business Strategy and the Environment, 16(5), 354-365.

Savage, R. L. (1985). When a Policy's Time has Come: Cases of Rapid Policy Diffusion, 1983-1984. Publius. 15(3), 111-125.

Sharp, E. B., Daley, D. M., \& Lynch, M. S. (2010). Understanding local adoption and implementation of climate change mitigation policy. Urban Affairs Review, 47(3), 433457.

Smith, C.D. (2013). Green Procurement in the Public Sector: Purchasing Departments as Procurement Entrepreneurs. In G.L. Albano, K.F. Snider, and K.V. Thai (Eds.), Charting a Course in Public Procurement Innovation and Knowledge Sharing (pp. 54-84). Boca Raton, FL: PrAcademic Press.

Snider, J., Hill, R., and Martin, D. (2003). Corporate Social Responsibility in the $21^{\text {st }}$ Century: A View of the World's Most Successful Firms. Journal of Business Ethics, 48(2). 175-187.

Studlar, D.T. (1999). Diffusion of Tobacco Control in North America. Annals of the American Academy of Political and Social Science. 566(11/1999). 68-79.

Terman, J. \& Feiock, R. (2014). Third-Party Federalism: Using Local Governments (and Their Contractors) to Implement National Policy. Publius: The Journal of Federalism, 45(2), 322-349.

Terman, J. (2014). A State-Level Examination of Bureaucratic Policymaking The Internal Organization of Attention. The American Review of Public Administration, Advanced Online Publication doi: 10.1177/0275074014529840

U.S. Environmental Protection Agency. (2000). Environmentally Preferable Purchasing. [Online]. Available at www.epa.gov. [Retrieved August 21, 2015].

U.S. Environmental Protection Agency. (2000). State and Local Government Pioneers: How State and Local Governments Are Implementing Environmentally Preferable Purchasing Practices. [Online]. Available at www.epa.gov. [Retrieved August 25, 2015].

Walker, J.L. (1969). The Diffusion of Innovations among the American States. The American Political Science Review. 63(3). p. 880-899.

Webb, D.J., Mohr, L.A., and Harris, K.E. (2008). "A Re-Examination of Socially Responsible Consumption and Its Measurement." Journal of Business Research, 61(2), 91-98. 


\section{Zhang, Y., \& Feiock, R. C. (2010). City managers' policy leadership in council-manager cities. Journal of Public Administration Research and Theory, 20(2), 461-476.}

\footnotetext{
${ }^{\mathrm{i}}$ One example of this consumer pressure is adoption of Environmental Management Systems (EMS), such as ISO 14000 series standards or the European Union's Eco-Management and Audit Scheme (EMAS), both of which include green purchasing components (Coggburn, 2004).

ii For example, the Commission for Environmental Cooperation (CEC) suggests that green procurement has the potential to stimulate innovative product and business development in addition to new product/service markets (CEC, 2003).

iii Upon review of the county websites, it was determined that, for the 50,000 - 499,999 population range, three counties did not have active county websites, fifteen counties did not have purchasing departments or perform purchasing functions, and an additional three counties did not have any purchasing materials available online. For the 500,000+ population range, five counties did not have any purchasing materials available online. These twenty-six counties were excluded from the study and the remaining county websites were reviewed for the information included in the table below.

iv We did not, however, use a formal test of interreliability.

${ }^{\mathrm{v}}$ Studies of corporate social responsibility (CSR), for example, demonstrate that companies use their websites to communicate their CSR activities to their shareholders (Snider et al., 2003; Maignan and Ralston, 2002; Ersock and Leichty, 2000). Because green purchasing by counties can be conceived of similarly and is a CSR activity in private companies, it is believed the county websites are used in much the same way, that those counties that are more engaged in green purchasing will promote it on their websites.

${ }^{v i}$ This field was initially conceptualized as having six possible responses, based on the categorizations in the NACo Toolkit: (1) broad, meaning there is a policy establishing some green purchasing priorities; (2) specific, meaning the policy mandates particular products such as recycled content requirements; (3) mandated, meaning the policy requires all county purchases to meet specific green guidelines; (4) discretionary, meaning the policy allows flexibility and permits staff to use their judgment; (5) formally-accepted administrative procedure, meaning a clear process is established but it is not a formal policy; or (6) none, meaning there is no evidence of a green purchasing policy. Upon collecting the data, it was discovered that most counties have products for which there was a formal and mandated EPP. However, for other products EPP's were suggestive (i.e. use green products one not cost prohibitive). And, in other cases, the purchase of particular materials were banned (i.e. styrofoam or harsh chemical products).

vii The economic census provides data for all petrol employees in the sector, which include white collar and production employees, in addition to production petrol employees only. The number of production employees only was used in order to prevent over-inflation of the sector measure, which would be caused by the inclusion of corporate petrol salaries.
} 